\title{
ÚJFAJTA SZIVÁRGÁSOK LEÍRÁSA A VALLOMÁSOK SORÁN, VIDEÓFELVÉTELEK ELEMZÉSÉVEL ${ }^{1,2}$
}

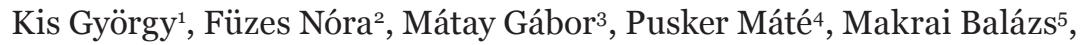 \\ Czabán Csaba ${ }^{6}$, Takács Szabolcs ${ }^{7}$ \\ ${ }^{1}$ ANIMA Polygraph Kft, Ügyvezető, \\ 2,3,4,5 Károli Gáspár Református Egyetem, Pszichológia Intézet, hallgató, \\ 6 ANIMA Polygraph Kft, pszichológus, PhD hallgató, \\ ${ }^{7}$ Károli Gáspár Református Egyetem, Pszichológia Intézet, egyetemi adjunktus
}

\begin{abstract}
Absztrakt
Cikksorozatunkban annak a kutatómunkának az eredményiről számolunk be, amelyet 2014-ben kezdtünk annak reményében, hogy különböző hazugságot elkövető típusokat tudtuk sikerrel jellemezni (Kis et al., 2017).

Vizsgálatunkban a korábbi hangvizsgálatokat kiegészítettük videók vizsgálatával, így lehetőségünk volt arra, hogy nem csak egyetlen csatornát, hanem több csatornát egy időben tudjuk megvizsgálni. Jelen cikkünkben bemutatjuk, hogy nem csak ,itt és most” jelzéseket tudtunk megfigyelni és dokumentálni, hanem jelzések egymásutánját is le tudtuk jegyezni. A vizsgálatban résztvevők minden esetben hozzájárulásukat adták a képi anyagok tudományos elemzésekben és közlésekben való felhasználásához.
\end{abstract}

\begin{abstract}
We hereby report about the results of a research work in these series of articles, which we have launched in 2014 in hope of successfully featuring different typologies of lies (Kis et al. 2017).

In our research the previous speech analysis were extended with video analysis, which enabled us to examine not only one but more channels at the same time. This article presents that not only hot-spot signals can be observed and documented but series of signals can be detected too. All participants signed a written document in which they declared: all video records can be used for further researches and academic publications.
\end{abstract}

Keywords: lie • LVA, speech analysis • deposition • video analysis

Research license 278/2016/P. All participants signed a written document in which they declared: all audio and video records can be used for further researches and academic publications.

$1 \quad$ Az etikai engedély iktatási száma: 278/2016/P

2 A cikk alapját Füzes Nóra, Mátay Gábor és Pusker Máté OTDK dolgozata szolgáltatja, melyet a XXXIII. OTDK alkalmával mutattak be. 


\section{BEVEZETŐ}

A hazugságkutató mühely jelen kutatását több előkészítő kutatás előzte meg, melyek eredményeit konferenciaelőadásokon bemutattuk. Ezen előkészületek során részint a hazugságok verbális és nonverbális jegyeinek vizsgálati lehetőségeit tárgyaltuk (Endrédi \& Benczúr, 2013; Takács \&Benczúr, 2013; Endrédi et al., 2015), részint pedig a hazugságdetekciós képességeket különböző csoportokban, helyzetekben (Tollner \& Benczúr, 2013; Koch et al., 2015).

A hazugságkutatók - bár többféle, olykor egymástól jelentősen eltérő megállapításokra jutnak - jórészt egyetértenek abban, hogy hazugságról akkor beszélhetünk, ha

- a hazugnak szándékában áll a megtévesztést elkövetni, tehát tudatosan igyekszik a valós tényektől eltérő információkat átadni a fogadó félnek;

- a hazug számára tétet jelent e szándék sikerre vitele: vagy valamilyen számára negatív következményt (pl. büntetést) kerül el vele, vagy pedig közvetlen nyeresége származik a megtévesztésből;

- a hazug tudja, hogy kockázatot vállal megtévesztő cselekedetével.

Kísérleteinkben három hazug típust (meghamisító, elhallgató, titkoló), valamint egy „státusváltó” típust (patetikus) vizsgáltunk. Jelen cikkünk a kihallgatásokon készített videófelvételek elemzési eredményeiről számol be.

A kutatási összefoglalóban (Kis et al., 2017) részletesen bemutattuk a maffia játékot, valamint annak szerepeit. Cikkünkben két szereplő hazugságtípus videóelemzésének eredményeit fogjuk bemutatni. A meghamisító és az elhallgató típusokra vonatkozó eredmények közül azokat, melyek kizárólag a hangelemzés segítségével voltak megállapíthatók, a kutatásunk első fázisában már korábban ismertettük (Czabán et al. 2017a, 2017b).

A kutatás második fázisában megismételtük a kísérletet és a kihallgatások során nem csak hanganyagok, hanem videófelvételek is készültek. A videófelvételek segítségével pedig nem csak a hang (mint csatorna) vált elemezhetővé, hanem az arckifejezések és a testbeszéd is. Így a videófelvételek és a hangfelvételek együttes elemzése során nem egyetlen, hanem három különböző csatorna elemzését végeztük el.

Egy kihallgatást ideális esetben körültekintően kell megtervezni és zavartalan körülmények között kell lefolytatni. Célszerű, ha a kihallgatást végző gyorsan tájékozódik a hazug (gyanúsított) viselkedéséről. Előre meg kell határozni a kihallgatási taktikát. Az esetek egy részében történik csak hangfelvétel, vagy/ és videófelvétel. A kihallgatónak jegyzőkönyvet kell készítenie a vallomásról, csak ritkán van arra lehetőség, hogy azt egy jegyzőkönyvvezető végezze, a kihallgató pedig csak a hazugra figyeljen. A szakirodalomból ismert, hogy pl. a mikrokifejezések, mint a hazugság szivárgása csak 1/25 másodpercig jelennek meg (Ekman, 2009). Ennek felfedéséhez gyakorlat és nagy koncentráció szük- 
séges. A legjobb megoldás, ha a kihallgató hang- (LVA) és videófelvételt is tud készíteni, ezzel nem foglalja le magát a jegyzőkönyv gépelésével és utólagosan is tud elemzéseket végrehajtani, így felkészülve a folytatólagos kihallgatásra. Az utólagos elemzések lehetőséget adnak arra, hogy minden hazugság csatorna egyenként elemzésre kerüljön, ezzel felfedve a szivárgásokat és a hazugság jeleket. Tudjuk, hogy a szivárgás elárulja, hogy a hazug miben hazudik. A megtévesztés jele választ ad arra a kérdésre, hogy valaki hazudik-e vagy sem, de nem ad választ arra, hogy mit rejt, leplez el a hazug. Erre csak a szivárgás képes (Ekman, 2009). Kiderül, hogy a kihallgatást végzőnek milyen összetett a feladata, mennyire felkészültnek kell lennie ahhoz, hogy sikerrel megoldja a kihallgatás folyamatát. Cikkünkben azt szándékozunk bemutatni, hogy a hang- és videófelvétel utólagos elemzése milyen nagy mértékben segíti a kihallgatást végzők munkáját, mennyivel hatékonyabban tudnak dönteni a folytatólagos kihallgatás taktikájáról.

\section{ELEMZÉSI MÓDSZERTAN BEMUTATÁSA}

A kísérlet pontos leírását korábbi cikkünk már tartalmazza (Kis et al., 2017). A videóelemzéssel kiegészített kísérletben még fontosabb szerep jutott a releváns és irreleváns kérdések váltakozásának, így ezeket újra bemutatjuk. Bevezető kérdések, amelyek az LVA kalibrálására szolgáltak:

- Mondja el, milyen jeligét választott!

- Idézze fel egy kellemes nyári emlékét!

A fenti kérdésekben tehát az LVA segítségével felmérjük, hogy a vizsgálati alanynak milyen az aktuális állapota - mihez kell majd viszonyítani a játék kapcsán elhangzó kérdésekre adott válaszait, azok minőségét. Megjegyezzük, hogy már e kérdések feltétele közben is forog a kamera, tehát már a bevezető kérdések során is rendelkezünk alapinformációkkal a vizsgálati alanyokról.

A bevezető kérdések után kezdődött a tényleges kihallgatás, melynek kérdései a következők voltak:

- Mondja el az eddigi éjszakák eseményeit!

- A nappalok során milyen gyanús eseményeket vett észre?

- Mi volt a kedvenc középiskolai tantárgya?

- Mi a kedvenc időtöltése?

- Kire gyanakszik, hogy maffiatag lehet? Mire alapozza ezt?

- Kire gyanakszik, hogy felügyelő lehet? Mire alapozza ezt?

- Mondja el egy átlagos napirendjét!

- Melyik játékostársában bízik? Miért?

- Milyen lelkületű embernek gondolja azt, aki maffiatagként megölt valakit?

- Mi a véleménye a játékról? 
Megfigyelhető, hogy a kísérleti helyzetre és teljesen független dolgokra egyaránt vonatkoznak kérdések, ráadásul váltakozva. Minden vizsgálati alany ugyanazokat a kérdéseket kapta - és szándékolt volt, hogy ne lehessen igen/nem válaszokkal „kibújni” a kérdések alól.

A kedvenc időtöltése, a napirendje vagy a kedvenc középiskolai tantárgyára vonatkozó kérdések két szerepet töltenek be:

- Egyik oldalról a vizsgálati alanyok releváns és irreleváns kérdésekre adott válaszai összehasonlíthatók egymással (mind videó-, mind hangelemzés során).

- Másik oldalról: ha valamely kérdés „megérinti”, akkor az olyan hatást válthat ki, mint a bokszolók esetében egy-egy nagyobb ütés. Az utóhatást néhány másodpercig még érzékelni fogja a szoftver - így meg kell várni ennek „lecsengését”. Tehát a releváns kérdések utáni irreleváns kérdéseknek az a hatása, hogy a hanganyagok kitisztulnak, a releváns kérdésekben a korábbi kérdések feszültsége minimális lesz.

Mint azt korábban említettük, a hangelemző rendszerek alkalmazása általában (miként bármely müszeres vizsgálat) szakértői hozzáértést igényelnek. A hanganyagok elemzésének szakértői irányítását Kis György (ANIMA Polygraph Kft.) végezte. A kielemzett maffiatag (meghamisító) és kollaboráns (elhallgató) hangfájlok értelmezésében a képzést Kis Györgytől és Madzin Andrástól kaptunk. A videóelemzés ${ }^{3}$ során három, egymástól független kódoló is végignézte a felvételeket - és csak azokat a jelzéseket fogadtuk el végül, melyeket egybehangzóan, minden kódoló egyaránt érzékelt. A videókat másodperces bontásokban, lassítva nézték végig a kódolók.

Azokat a mozzanatokat (legyen az egy szemöldökráncolás vagy kézmozdulat), melyekre nem érkezett egyöntetü értékelés, konszenzusos döntés alapján, szakértői segítséggel (ANIMA Polygraph szakértői) értékeltük egy újabb megtekintés után.

A releváns jeleket négy fó csoportba osztottuk, ezen csoportok voltak az arc-, test-, beszéd-, illetve „egyéb” kategóriák. Az elemzés során a globális megfigyelés mellett az elóbb említett kategóriákat figyeltük felváltva. A videók elemzése alatt a legnagyobb erőfeszítést az arc pontos monitorozása jelentette. Az ilyen kérdéses jelzéseket többségében képkockánként lassítottuk le és elemeztük, míg egységes álláspontra jutottunk.

Látható: az arcra vonatkozó jelzéseknél nem volt elég a másodpercenkénti lassítás. A videófelvételek HD minőségére éppen azért volt szükség, mert (Ekman, 2007) az arcon található mikrokifejezések, illetve akár egyéb csatornákon való szivárgások a másodperc tört része alatt lezajlanak, így a másodpercenkénti 25-

\footnotetext{
3 A korábbi cikkekben (Czabán és társai 2017a, 2017b, illetve Madzin és társai, 2017c és 2017d)
} már szóltunk a kizárólag hangelemzéssel elért eredményekről, így ezeket itt nem ismertetjük. 
50 képkockás lassítások teszik lehetővé azt, hogy objektív megfigyelést hajthassunk végre.

A fentiekből is kitünik, hogy ezek alapján egy-egy videóelemzés (szemben a hangelemzés müszeres vizsgálatával), egy 7-8 perces videó esetében egy teljes munkanapot tett ki (3 elemzővel, illetve akár további szakértő bevonásával).

\section{VIDEÓELEMZÉS EREDMÉNYEI}

Az alapkoncepciónk az elemzések során az volt, hogy a pozitív találatok esetében tetten érhető jelzésekre koncentráltunk. A másik két típus (eltitkoló és patetikus), melyekről (Madzin et al., 2017aa, 2017b) már szóltunk, tartalmaz egy fals jelzést szolgáltató típust, illetve egy kevert tipológiát. Így a titkoló és a patetikus elemzésével a kutatás ezen szakaszában még nem foglalkozunk. Azt feltételeztük, hogy az elhallgató és a meghamisító típusok szivárgásai más csatornákon, illetve a csatornák más és más kombinációin érhetők tetten.

Első lépésben azt vizsgáltuk, hogy a felsorolt négy csatorna másként múködik-e a két szerepben? Ehhez kereszttáblás elemzést (1. táblázat) alkalmaztunk, mely kereszttábla az alábbi információkat tartalmazta:

1. táblázat

SZEREP * Jegyek, szűkített kategóriák kereszttábla

\begin{tabular}{|c|c|c|c|c|c|c|}
\hline & & \multicolumn{4}{|c|}{ Jegyek, szükített kategóriák } & \multirow[t]{2}{*}{ Összes } \\
\hline & & $\operatorname{Arc}$ & Test & Beszéd & Egyéb & \\
\hline \multirow{4}{*}{ Kollaboráns - elhallgató } & Esetszám & 173 & 103 & 7 & 17 & 300 \\
\hline & Becsült érték & 168,5 & 104,5 & 12,4 & 14,6 & 300,0 \\
\hline & Korrigált eltérés & 8 &,- 3 & $-2,4$ & 1,0 & \\
\hline & Esetszám & 127 & 83 & 15 & 9 & 234 \\
\hline \multirow[t]{2}{*}{ Maffiatag - meghamisító } & Becsült érték & 131,5 & 81,5 & 9,6 & 11,4 & 234,0 \\
\hline & Korrigált eltérés &,- 8 & 3 & 2,4 & $-1,0$ & \\
\hline \multirow{2}{*}{ Összesen } & Esetszám & 300 & 186 & 22 & 26 & 534 \\
\hline & Becsült érték & 300,0 & 186,0 & 22,0 & 26,0 & 534,0 \\
\hline
\end{tabular}

A khi-négyzet próba alapján (khi2(3) $=6,517, \mathrm{p}=0,089, \mathrm{~V}=0,11)$ tendencia-szintű eltérés mutatható ki a szerepek és a jelzések között. A reziduálisok alapján (korrigált eltérések) elmondható, hogy ez a tendenciaszintű eltérés a beszédben mutatkozó különbségekben mutatkozik meg (2-nél nagyobb abszolútérték esetében vehető jelzés értékűnek az eltérés). 
A reziduálisok alapján azt mondhatjuk, hogy a meghamisítók esetében a beszédben több jelzést tudunk tetten érni, mint az elhallgatók esetében.

Az khi-négyzet próba után loglineáris modellezés segítségével igyekeztünk azt feltárni, hogy az LVA jelzései, a videóelemzések eredményei és a vizsgált szerepek közül mely kombinációk azok, melyek elegendő információt szolgáltathatnak ahhoz, hogy valamilyen módon egységes képet alkothassunk.

2. táblázat

Loglineáris modell illeszkedésvizsgálata

\begin{tabular}{llll}
\hline & Érték & df & Sig. \\
\hline Likelihood Arány & 35,923 & 24 &, 056 \\
Pearson khi-négyzet & 35,183 & 24 &, 066 \\
\hline
\end{tabular}

a. Modell: Poisson

b. Design: Konstans + SZEREP * LVA_kategória + jegy(videó) + SZEREP * jegy(videó)

A loglineáris modell illeszkedésének magyarázata (2. táblázat): Amikor már nagyobb modellt készítünk (a szerep- és a hangelemzés együttes információja, illetve a szerep és a jegyek együttes információja mellé pusztán a kapott külső jelzéseket is figyelembe vesszük), megfelelő illeszkedést tudunk elérni (nem szignifikáns az eltérés, khi2(24) =35,183, SIG=0,066).

Ez a gyakorlati oldalról az alábbiakat jelenti: ha ismertek a különböző szerepek (meghamisító és elhallgató) specifikusan hangelemzésből származó sajátosságai (lásd Kis et al. 2017a, 2017b anyagai), valamint a szerepek videóelemzésből származó kategóriái, továbbá általánosságban ismerjük azt, hogy egy-egy videóelemzésen milyen jelzéseket tapasztalunk, úgy e három információból feltárhatók a tipológiák összesített specifikumai (nem kell minden szerep, minden hangelemzés és minden videóelemzés együttes információja). Azaz: ha egy szakértôtől szerep- és videósajátosságot, míg egy másiktól egy szerep- és hangelemzés sajátosságot kapunk, úgy a két információ „összeilleszthető” - valószínűsíthetô az adott képi és hanganyag szerep szerinti kategorizálása. ${ }^{4}$

Az LVA jelzéseit 5 kategóriába osztottuk: nincsen jelzés, pontatlanságot jelez a gép, feszültséget, hamis állítást vagy valamely egyéb jelzést kapunk (például bizonytalanság) ${ }^{5}$. Emellett vizsgáltuk a videóelemzés kategóriát a kétfajta szerepben, típusban.

\footnotetext{
4 Az egyik célkitűzésünket, miszerint egyfajta stratégiát, elemzési irányt is javasolni tudunk a módszer mellé, teljesítettük. Természetesen ez nem jelenti azt, hogy teljes képet kaptunk - de az irány, melyet ennek segítségével megalkothatunk, a kapott eredmények alapján járható utat jelent. 5 Az összefoglaló tanulmányban (Kis és társai, 2017) említettük, hogy az LVA hangelemző eljárás kockázati jelzést ad - mely jelzéseket további elemzések segítségével fogunk hazugságként értékelni, amennyiben a különböző paraméterek együttállásai alapján ez a szakértői álláspont.
} 
KIS-FÜZES-MÁTAY-PUSKER-MAKRAI-CZABÁN-TAKÁCS

\section{3. táblázat}

A loglineáris modell tapasztalati és becsült kereszttáblája

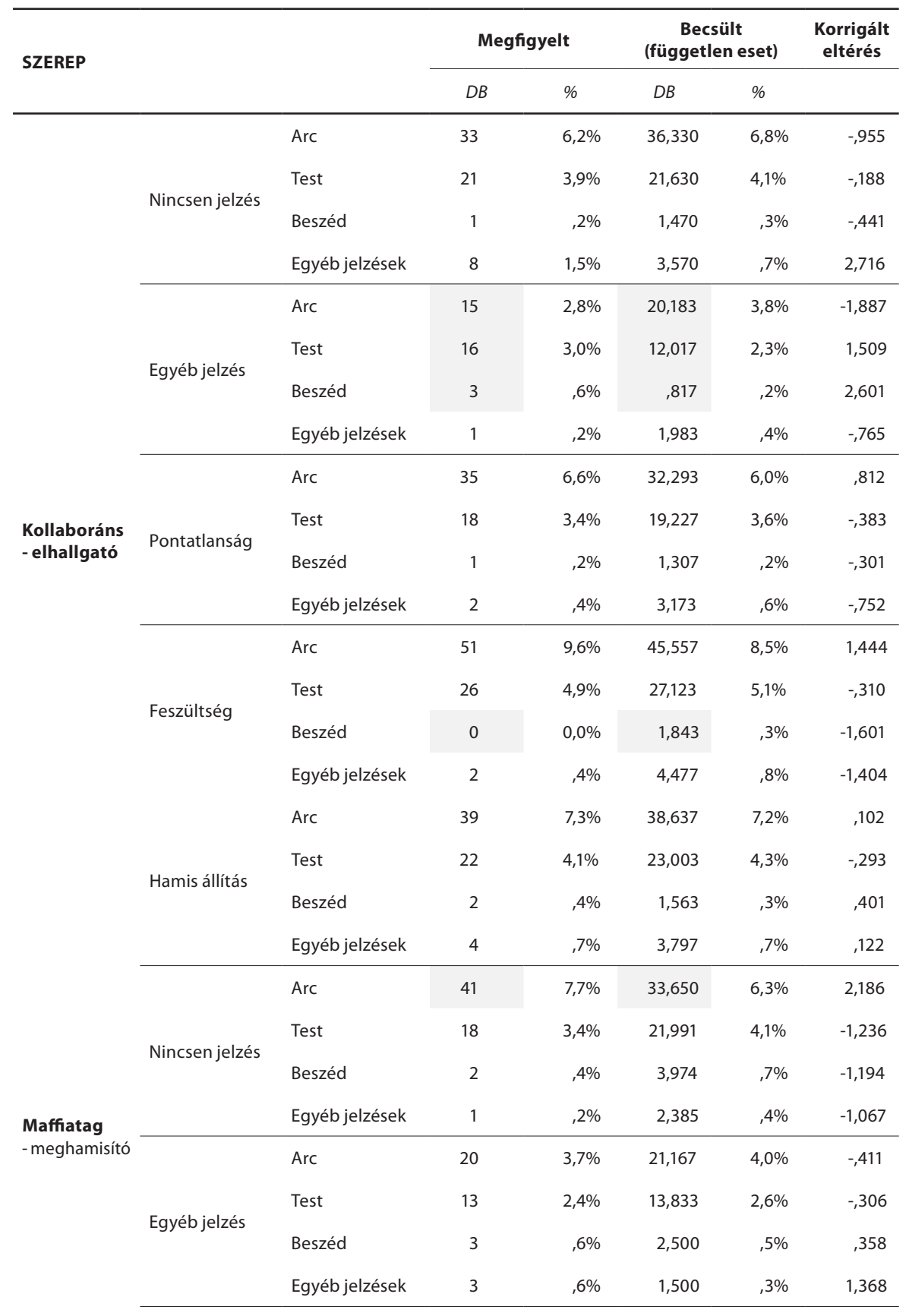




\begin{tabular}{|c|c|c|c|c|c|c|c|}
\hline & & Arc & 41 & $7,7 \%$ & 33,650 & $6,3 \%$ & 2,186 \\
\hline & & Test & 18 & $3,4 \%$ & 21,991 & $4,1 \%$ & $-1,236$ \\
\hline & Tumasenjelacs & Beszéd & 2 &, $4 \%$ & 3,974 & ,7\% & $-1,194$ \\
\hline & & Egyéb jelzések & 1 & ,2\% & 2,385 & ,4\% & $-1,067$ \\
\hline & & Arc & 20 & $3,7 \%$ & 21,167 & $4,0 \%$ &,- 411 \\
\hline & & Test & 13 & $2,4 \%$ & 13,833 & $2,6 \%$ &,- 306 \\
\hline & & Beszéd & 3 & ,6\% & 2,500 &, $5 \%$ & 358 \\
\hline & & Egyéb jelzések & 3 & ,6\% & 1,500 & ,3\% & 1,368 \\
\hline & & Arc & 26 & $4,9 \%$ & 27,679 & $5,2 \%$ &,- 534 \\
\hline Maffiatag & & Test & 18 & $3,4 \%$ & 18,090 & $3,4 \%$ &,- 030 \\
\hline & & Beszéd & 5 & ,9\% & 3,269 & ,6\% & 1,119 \\
\hline & & Egyéb jelzések & 2 & ,4\% & 1,962 & , 4\% & ,032 \\
\hline & & Arc & 15 & $2,8 \%$ & 20,081 & $3,8 \%$ & $-1,828$ \\
\hline & & Test & 15 & $2,8 \%$ & 13,124 & $2,5 \%$ & 703 \\
\hline & & Beszéd & 5 & ,9\% & 2,372 & ,4\% & 1,923 \\
\hline & & Egyéb jelzések & 2 & ,4\% & 1,423 & ,3\% & ,538 \\
\hline & & Arc & 25 & $4,7 \%$ & 24,423 & $4,6 \%$ & 192 \\
\hline & & Test & 19 & $3,6 \%$ & 15,962 & $3,0 \%$ & 1,053 \\
\hline & & Beszéd & 0 & $0,0 \%$ & 2,885 & ,5\% & $-1,953$ \\
\hline & & Egyéb jelzések & 1 & , 2\% & 1,731 & ,3\% &,- 630 \\
\hline
\end{tabular}

Az illeszkedés vizsgálatakor azokat a cellákat emeltük ki, melyek esetében a korrigált eltérések (kicsit szigorúbban a khi-négyzet próbánál) 1,5-nél nagyobb eltérést mutattak (akár pozitív, akár negatív irányban).

Láthatók az alábbiak:

- A meghamisító esetében az arc (kevesebb jel, jobban kell rá figyelni) és a szemmozgás az, amire figyelni kell, egyéb hangelemzési jelzések esetében, illetve feszültség során a beszéd lehet árulkodó.

- Az elhallgató esetében egyértelmúen az arcjelzések lehetnek árulkodók fóként akkor, ha a hangelemzés kevés jelzést ad, illetve feszültséget és S.O.S. jelzést mutat.

Megjegyezzük tehát, hogy ha a hangelemzés feszültség jelzést mutat, akkor a meghamisító esetében a beszédük (verbális tartalom elemzése LVA-val), míg az elhallgató esetében a mimikájuk (arcuk) lehet árulkodó. Az arc jelzéseinél érde- 
mes ellenőrizni, hogy az LVA ad-e S.O.S. ${ }^{6}$ jelzést, ami annak a jele, hogy a hazug az adott kérdésről nem akar beszélni, elhallgat információkat.

A videóelemzések során a fenti kategóriák (arc, beszéd, test, egyéb) az alábbiakat jelenti, kiemelve a fontos, szakértők által is megerősített jelzéseket:

\section{4. táblázat}

Jellegzetes jelzések a videóelemzések alapján a két típus elkülönítésére

\begin{tabular}{ll}
\hline Elhallgató & Meghamisító \\
\hline kéz és lábösszeszorítás, láblengetés & mosoly (sok esetben szemöldök mozgás követi) \\
vállrántás & aktív szájmozgás (nyalás, elhúzás, összeszorítás) \\
szemöldök összehúzása & lefelé nézés \\
száj megnyalása & visszakérdezés \\
száj csattanása & szemöldök mozgás \\
EB⿱ arckifejezés & \\
kézkörzés & \\
fel- és lenézés & \\
mosoly (zavart mosoly)
\end{tabular}

E fenti eredmények tehát azok, melyeket a hangelemzéssel egyidőben tudtunk megfigyelni, azaz a videóelemzések során is észrevettük (3 egymástól független kódoló, szakértők által megerősítve), illetve a hangelemzés során is igazolást nyert az adott hangszegmensben való jelzés.

Bemutatjuk néhány illusztratív képpel, hogy a két típusra milyen jellemző gesztusokat, mozdulatokat, arcon megfigyelhető szivárgásokat lehetett tetten érni. (A képeken szereplő személyek írásban beleegyeztek a róluk készült felvételek publikálásába.)

\section{AZ ELHALLGATÓ}

E kihallgatási helyzetben a kihallgatott, bár nem állít valótlanságot, leplezi az igazságot, tehát visszatartja az információt. Általános szófordulatuk lehet: „Nem tudom!", Nem emlékszem!”. Megfigyelhetően aktívabb a viselkedésük, mint a meghamisítónak. Kihallgatási helyzetben kevésbé kontrollálják magukat, bár erre kevésbé is van szükségük, hiszen kisebb kognitív erőfeszítést kell tenniük, mintha egy teljesen új történetet kellene kitalálniuk és előadniuk (Ekman, 2007).

6 S.O.S: Mondjam vagy megálljak jelzés, bővebben lásd az LVA paramétereket.

7 Az EB (Elgondolkodó, bambuló) arckifejezést később ábrával is illusztráljuk. 
A legszembetűnőbb viselkedésbeli jellegzetességük, hogy feltűnően sok a kéz- és lábmozgás, valamint a szemöldök aktívabb mozgása. Nincs kifejezett jobb, illetve baloldali dominancia, csupán a végtagok aktívabb és nagyobb mozgása figyelhető meg. Továbbá fontos kiemelni azt is, hogy míg a meghamisító jellemzően lefelé, addig az elhallgató fel-, illetve lefelé néz.

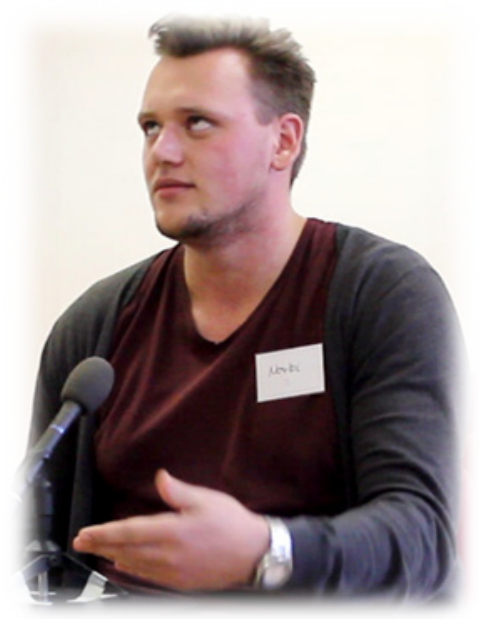

1. ábra. Aktívabb kézmozdulatok, felfelé irányuló tekintet

Az aktívabb kézmozdulatok mellett (1. ábra) a felfelé irányuló tekintet erôteljes hatása figyelhető meg az 1. ábrán. Továbbá a vállak intenzívebb mozgása (2. ábra) mellett ki kell emelnünk a kézmozgást (vakarózást) is, melyek az elhallgató hazugságnak régóta elismert, bizonyított jelei.

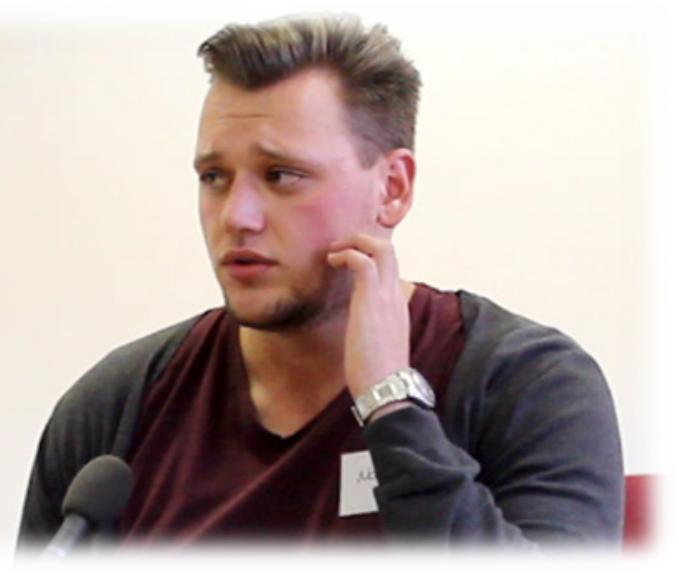

2. ábra. Vállak intenzívebb mozgása 
Felhívjuk a figyelmet mindkét esetben a megfogalmazásra: aktívabb, intenzívebb mozgás. Itt minden esetben úgy kell értelmeznünk, hogy az egyén „általában” vett, nyugalmi állapotához képesti eltéréseket detektáljuk - tehát a releváns helyzetben való eltérést rögzítjük!

Bár az elhallgatókhoz képest jelentősen többször látható aktív szájmozgás a meghamisítók esetében, mégis fontosnak tartjuk kiemelni a szájszárazság miatti szájnyalogatást (3. ábra), amely szintén a stressz és sok esetben a hazugság egyik már ismert jele.

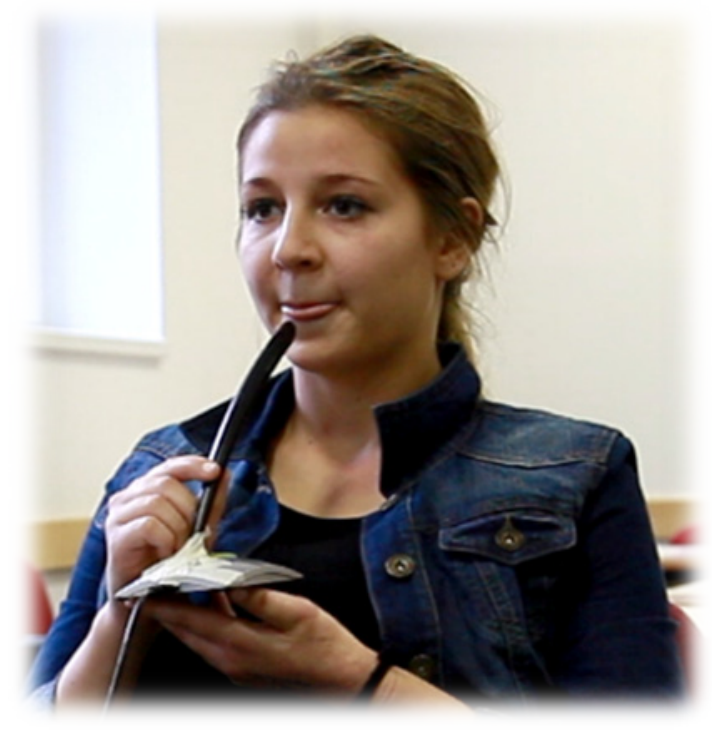

3. ábra. Szájnyalogatás

Itt fontos még megemlítenünk a száj csattanó hangját (4. ábra), amelyet sokszor a hazugság előtti pillanatban hallhattunk és láthattunk. Igyekeztünk a képpel (4. ábra) megragadni a lényegét, bár ennek sokkal inkább auditív, mint vizuális jelzése van.

Kiemeljük tehát, hogy nem csak jeleket, hanem jelek kombinációit, illetve jelek sorozatát is módunkban állt megfigyelni, feljegyezni! Ez különösen azért fontos, mert a hazugságvizsgálatokban (lásd Kis et al., 2017) már elmondtuk: itt és most eljárások vannak. Az eljárások tehát egy-egy jelzésre figyelnek - míg a kidolgozott módszertannal, illetve a „konzerválással” ezek sorozatai, kombinációi is tetten érhetők. 


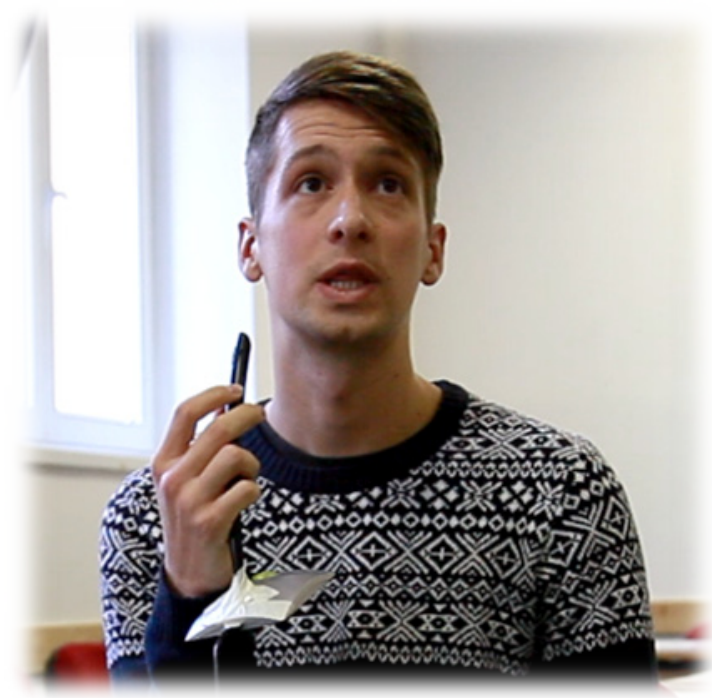

4. ábra. Szájcsattanás

Több elhallgató személynél megjelenik egyfajta „EB arckifejezés”, amelyet mi neveztünk el a könnyebb kommunikáció és a könnyebb besorolás kedvéért. Az EB szó az elgondolkodó, bámészkodó arckifejezés rövidítésére vonatkozik (5. ábra).

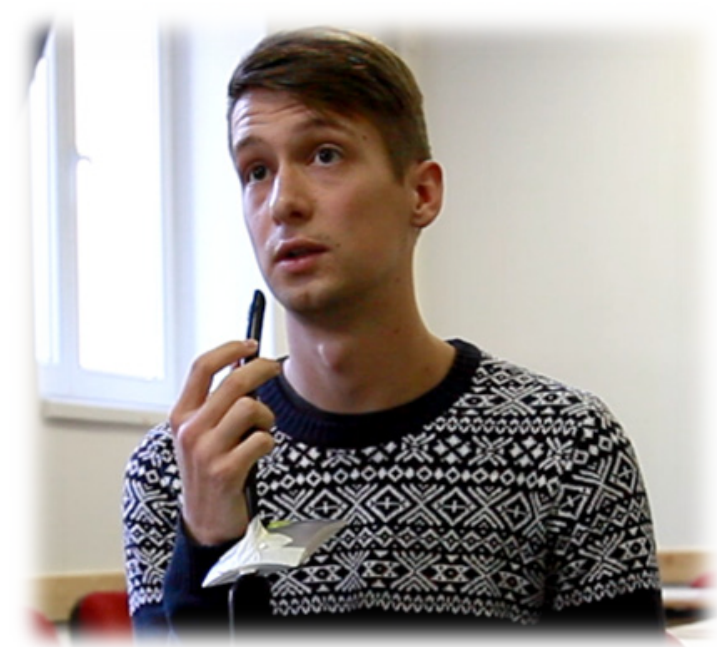

5. ábra. „EB" arckifejezés 
Az elhallgató jellemzésének kezdetén említettük a feltűnően sok kéz- és lábmozgást. Ezek közül szeretnénk kiemelni a kézkörzést, mint gesztikulációs elemet (6. ábra). Ez a mozgásfajta több esetben is megjelent, ezért tartjuk fontosnak külön kiemelni.

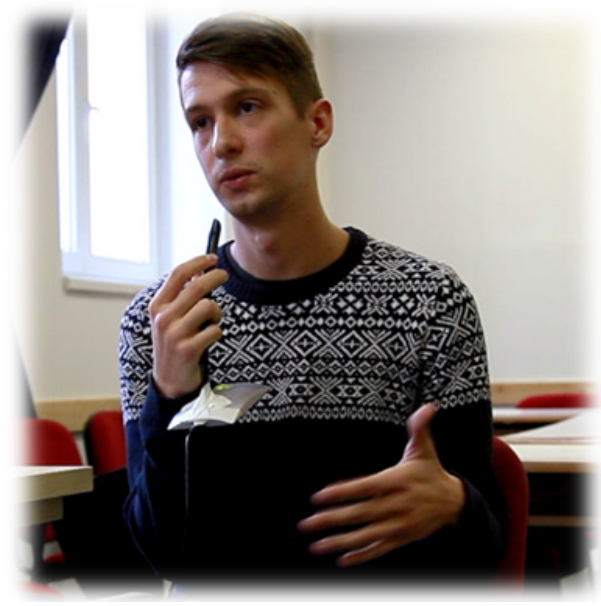

6. ábra. Kézkörzés, mint specifikus kézmozgás

A következő felismert jelzés, mely az elhallgató esetén jelentős volt a tekintet leilletve felemelése, valamint a le- és felnézés (1. ábra). Itt sem állapítható meg egyértelmüen jobb, illetve baloldali dominancia. A sor végét zárja a zavart (vagy ezzel ellentétesen, az egyértelmú) mosoly jelensége. Az átverés felett érzett siker generálta mosoly (7. ábra) egyértelmü - míg a meghamisító esetében illusztrálni fogjuk a zavart mosoly jelenségét is.

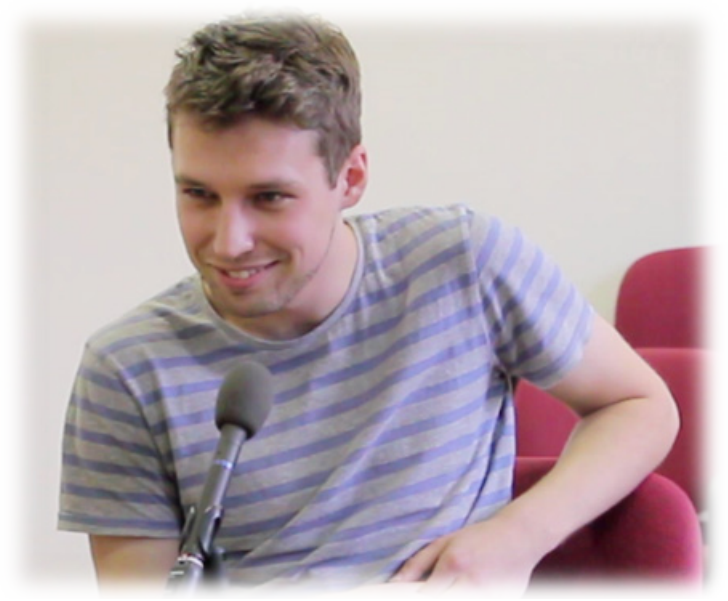

7. ábra. Átverés sikeressége felett érzett, örömöt kifejező mosoly 


\section{A MEGHAMISÍTÓ}

A meghamisító az a személy, aki tudatosan mást állít, mint a valóság. Hamis állításokat tesz, amely rendkívül nagy kognitív erőfeszítést igényel. Egyszerre kell minden csatornát a felügyelete alatt tartania, ami szinte lehetetlen küldetés. Ez okozza a szivárgást, illetve jelet, amelynek lenyomatai megmutatkoztak videó- és hangelemzéseink alatt.

A meghamisítókra leginkább jellemző viselkedéses jegy, amely minden elemzett videón fellelhető volt: a mosolygás. Különbséget kell tenni a zavart és kissé megvető mosoly között. Míg valaki az átverés felett érzett öröm miatti, már-már lekicsinylő mosolyt (8. ábra) produkálta:

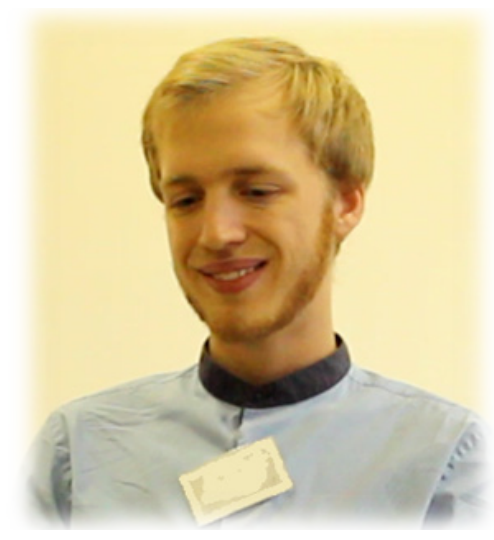

8. ábra. Sikeres átverés esetében mutatott öröm mosoly (megvető, lekicsinylő mosoly)

Ezzel szemben a zavart mosoly vagy kényszermosoly (9. ábra) az alábbiakban figyelhető meg:

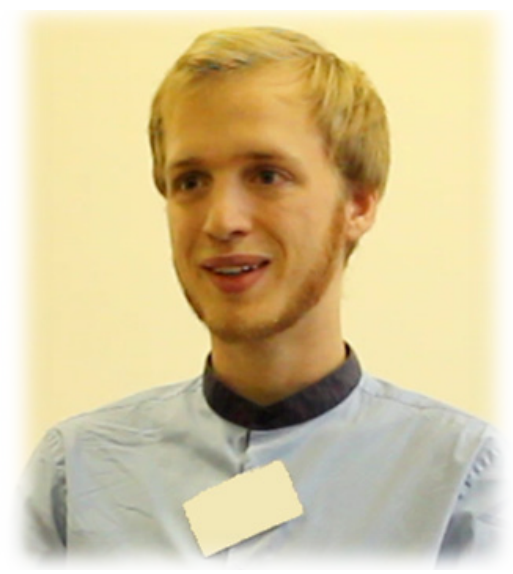

9. ábra. Zavart mosoly 
A hazugság és az öröm szorosan összekapcsolódhat, ezért ez a fajta mosoly már régóta ismert a szakirodalomban. Paul Ekman, a téma híres szakértője és Joe Navarro, volt FBI ügynök is kiemelten foglalkozott a témával (Ekman, 2010), de lényegében valamennyi hazugságkutató és viselkedéselemző ide sorolható lenne.

A meghamisítókra szintén globálisan jellemző viselkedéses jegy az aktív szájmozgás. Ide sorolható a jobb- vagy baloldalra elhúzott száj, a szájbiggyesztés (10. ábra), amely az alsó ajak kissé előre és felfelé tolását jelenti, melynél anynyira elvékonyodnak az ajkak, hogy szinte el is tünnek. Időnként orcafelfújás is társul hozzá, de ez nem törvényszerú.

Ennél a jelenségnél olyan érzése támad a szemlélőnek, mintha a vizsgálati alany szinte önmagát akarná elhallgattatni, s amely teljesen egybevág a hazug éppen aktuális cselekedetével, tehát az információ visszatartásával.

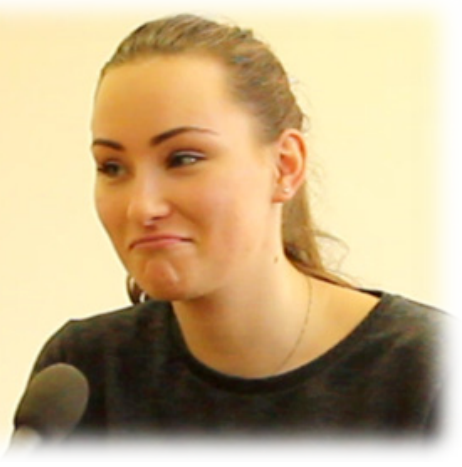

10. ábra. Szájbiggyesztés

A szájmozgások közé soroljuk továbbá a száj beharapását, a szájsarok felfelé tolását, amelyhez sokszor tartozik egy féloldali szájfelfújás, amely csak egy villanásig látható, valamint ide tartozik az elhallgató személyeknél is megjelenő szájnyalogatást. Itt is felhívnánk a figyelmet arra, hogy jelzések kombinációjáról van szó, tehát több jel együttes megjelenéséről.

Ezen kívül megfigyeltünk egy bizonyos fordított U alakú szájtartást (11. ábra), amely szintén több személynél megjelenik, s melyet az alábbi képpel szeretnénk illusztrálni: 


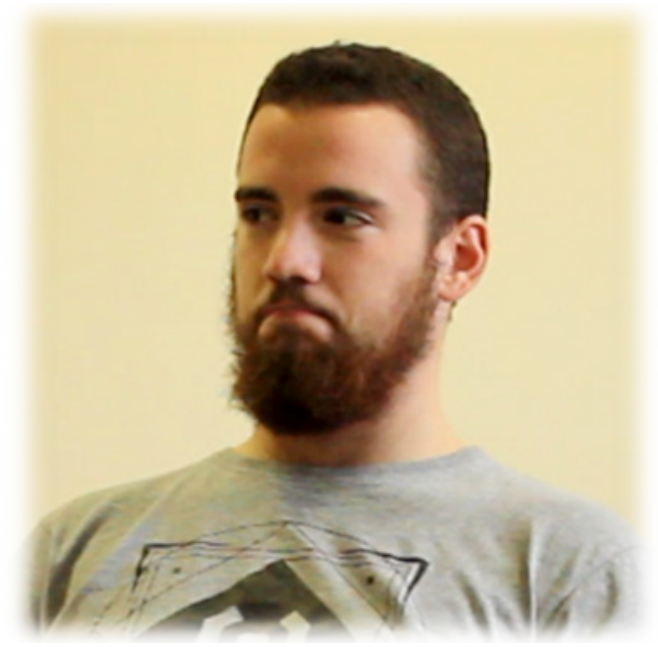

11. ábra. Fordított U alakú száj

Az elhallgatóknál említett le- és felnézés a meghamisítóknál is megjelent, bár itt a lefelé fordított tekintet volt elsősorban a domináns. Ezt alapvetően a szégyennek és a kognitív erőfeszítésnek tulajdonítjuk. A következő megfigyelt jelenség a visszakérdezés. Feltűnően sokszor kérdeztek vissza teljesen egyértelmü kérdések feltétele után a személyek, mellyel valószínúleg időt akartak nyerni, hogy kitalálhassák a választ, vagy éppen arra voltak kíváncsiak, hogy a vizsgálatvezető elfogadja-e állításaikat, hazugságaikat. Miután elég jelentős kognitív leterheltség alatt állnak hazugság közben, így szükségük is van rá. Sokszor követi a visszakérdezést a felsőtest kisebb mozgása vagy egy félszeg mosoly. Utána pár másodperc csönd következik, amely alatt igyekeznek kitalálni a minél hitelesebben hangzó hazug válaszukat. Itt arra külön felhívjuk a figyelmet, hogy ez esetben a jelzések egymást követö mivolta külön csatornákon történik - melynek megfigyelésére, feljegyzésére nem lenne módunk akkor, ha itt és most technikákat alkalmaznánk úgy, hogy kizárólag egy-egy csatornára figyelnénk!

A hazugoknál szintén jelentős a szemöldökmozgás (12. ábra), melyeknél több fajtát különítettünk el, viszont nem találtunk egyértelműen jobb vagy baloldali dominanciát. A szemöldökmozgások egyik típusa, amikor a szemöldök felfelé mozdul, a szem valamelyik irányba oldalra vagy lefelé sandít, melytől riadttá válik a tekintet. Ez a jelenség nem meglepő, hiszen kikérdezési helyzetben könynyen sarokba szorítva érezheti magát a meghamisító. A szemöldökmozgások másik típusa, amikor az alsó szemhéj megfeszül, a szemöldök csaknem a homlok közepére szalad, s közben összeráncosodik a homlok. Itt inkább csodálkozásról vagy meglepettségről, mintsem félelemről lehet szó. Ez sem meglepő, hiszen egy-egy kérdés váratlanul érheti a hazugot, melyre esetleg nem számított, s emiatt nincs még kész válasza rá. 


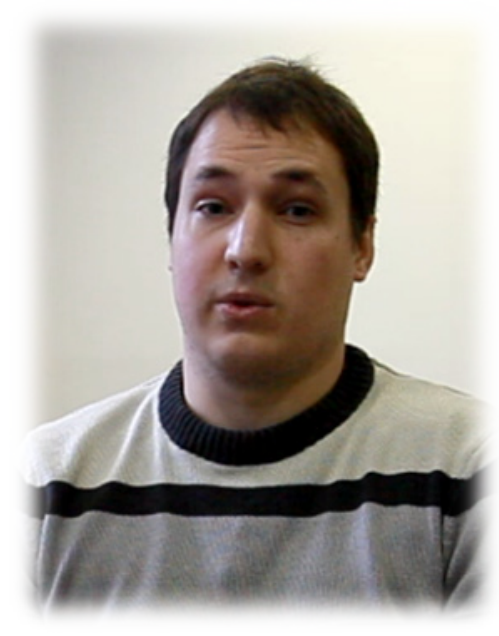

12. ábra. Szemöldökmozgás

Összefoglalva elmondhatjuk, hogy bár sok - akár a megtévesztésig hasonló jelzés figyelhető meg a két tipológiánál, mégis van, ami megkülönbözteti őket. Az elhallgató személynél sokkal inkább jelentősek a nagyobb testmozgások, ide értve a karokkal, illetve lábakkal történő manipulálást, kézkörzést, illetve a vállak mozgását. A meghamisítónál sokkal inkább szembetűnő az arc, illetve szemek aktív mozgása.

Tehát elmondhatjuk, hogy az elhallgatónál megjelenő kisebb kognitív terhelés némiképp szabadabb mozgásra ad lehetôséget. Ezzel szemben a meghamisító személyek teste szinte oda van szögezve a kikérdező székhez. Ennek oka, hogy a hazugok igyekeznek minimalizálni a mozgást, ezzel is elzárva az utat a lelepleződés elől.

\section{DISZKUSSZIÓ ÉS KITEKINTÉS}

Elemzéseink összefoglalásaként elmondhatjuk, hogy a fentiekben megfogalmazott hipotézisünk, mely szerint a különböző hazugságtípusok (elhallgató és meghamisító) viselkedéses jegyei másfajta csatornákon érhetők tetten, beigazolódott. Ezen állítást alátámasztja, hogy a megfigyeléseink és kutatómunkánk során külön viselkedéses jegyeket sikerült hozzárendelnünk az elhallgató és a meghamisító hazugságtipológiákhoz.

Megfigyeléseink szerint az elhallgató személyek több és nagyobb testmozgást (például Biland, 2009), míg a meghamisítók több mimikai, azaz arcon megjelenő viselkedéses jegyet produkálnak tanúvallomásuk megtétele alatt (például Ekman, 2010). 
A vizsgálat során találkoztunk néhány, a kutatást gyengítő tényezővel is, melyek a következők: néhány esetben nem volt megfelelő a kihallgatott személy érzelmi bevonódása (még a gondos, többszörösen elmondott és kihangsúlyozott szabályok ellenére sem). E vizsgálati alanyok egy részénél a kísérleti helyzetnek nem volt igazi tétje, melyet az LVA elemzések alkalmával láttunk is. Erre a jövőben megismétlésre kerülő felvételekénél külön figyelmet fogunk fordítani. A kutatást érdemes megismételni szélesebb körben, melybe beletartozna mind korosztályra, mind lakhelyre vonatkozó szélesebb körü mintavételezés - ezeket a tényezőket jelenleg kontroll kísérletekkel és adatgyưjtéssel igyekszünk orvosolni, lásd Kis és társainak összefoglaló cikke (2017), melyben külön kitérnek e vizsgálat kontroll kísérleteire, elemzéseire.

A kutatásból így is számos olyan eredmény született (jelzések kombinációi és/vagy sorozatuk, valamint az elemzési módszertanból származó akár értékelésben is felhasználható elemzési stratégiai irány), amiket eddig a szakirodalomban nem említettek. Lehetőségünk van a jövőben folytatni a munkát, így még pontosabb képet kaphatunk a hazugságban rejlö tipológiák különbözőségeiről és hasonlóságairól. Szándékunk szerint így hozzájárulunk ahhoz, hogy leegyszerüsödjön, ezáltal sikeresebbé váljon az egyébként oly nehezen tetten érhető hazugságok felismerése és vizsgálata.

Fontos kiemelnünk továbbá azt, hogy a vizsgálatunk során kidolgoztunk egy olyan új módszertant, melynek segítségével utólagosan lehet akár a korábbi Hot Spot (itt és most), akár az általunk létrehozott (teljes történetet egyben értékelő) elemzéseket elvégezni. Így egy-egy helyzetben nem kell akkor és ott döntéseket hoznunk. Ehelyett precízebben, pontosabban, hosszabb ideig tartó megfigyelésekkel, tehát kevesebb koncentrált energiával tudunk elemezni. Mindezt úgy tehetjük meg, hogy az eddigi tapasztalataink alapján a gyakorlatba is átültethető stratégiákat alkottunk. A bűnüldözésből származó kontroll adatok azt mutatják, hogy a kidolgozott módszertannal hatékony elemzési eszközt alkottunk a témával éles helyzetben, frontvonalban dolgozó felhasználók számára is.

\section{BIBLIOGRÁFIA}

Biland, C. (2009). A hazugság pszichológiája. Budapest: Háttér Kiadó.

Ekman, P. (2007). Leleplezett érzelmek: Az arckifejezések és az érzelmek felismerése a kommunikáció és az érzelmi élet fejlesztéséhez. Budapest: Kelly.

Ekman, P. (2010). Beszédes hazugságok. Budapest: Kelly Kiadó Kft.

Endrédi Zs., \& Benczúr L. (2013). A látszat néha csal: verbális és nonverbális jegyek szerepe a hazugság felismerésében. Előadás a Magyar Pszichológiai Társaság XXII. Országos Tudományos Nagygyúlésén. Budapest, 2013. június 5-7. In Vargha A. (2013). Kapcsolataink világa. A Magyar Pszichológiai Társaság XXII. Országos Tudományos Nagygyúlésének Kivonatkötete, MPT, p. 33. 


\section{KIS-FÜZES-MÁTAY-PUSKER-MAKRAI-CZABÁN-TAKÁCS}

Endrédi Zs., Tollner V., Kis Gy. \& Benczúr L. (2015). A hazugság-felismerés kognitív szempontú lehetőségei. Előadás a Magyar Pszichológiai Társaság XXIV. Tudományos Nagygyưlésén, 2015. május 28-30. Eger. In Lélek-net a léleknek: Az ember a változó technikai közegek világában. (Kivonatkötet). p. 84 .

Koch B., Kis Gy., \& Benczúr L. (2015). A közösségi oldalak, mint hazugságaink iskolái. Előadás a Magyar Pszichológiai Társaság XXIV. Tudományos Nagygyűlésén, 2015. május 28-30. Eger. In Lélek-net a léleknek: Az ember a változó technikai közegek világában. (Kivonatkötet). p. 85.

Takács E. \& Benczúr L. (2013). A verbalitás és mimika szerepe a hazugságdetekcióban. Előadás a Magyar Pszichológiai Társaság XXII. Országos Tudományos Nagygyưlésén. Budapest, 2013. június 5-7. In Vargha A. (2013). Kapcsolataink világa. A Magyar Pszichológiai Társaság XXII. Országos Tudományos Nagygyúlésének Kivonatkötete, MPT, p. 33.

Tollner V. \& Benczúr L. (2013). Hallássérült, látássérült és egészséges személyek hazugság-felismerési különbségei. Előadás a Magyar Pszichológiai Társaság XXII. Országos Tudományos Nagygyưlésén. Budapest, 2013. június 5-7. In Vargha A. (2013). Kapcsolataink világa. A Magyar Pszichológiai Társaság XXII. Országos Tudományos Nagygyúlésének Kivonatkötete, MPT, p. 34.

\section{Tematikus szám hivatkozott cikkei}

Kis, Gy., Takács, Sz., Liberman, A., Benczúr, L. (2017). A megtévesztés tipológiája - összefoglaló tanulmány. Psychologia Hungarica Caroliensis, 4(2), 2016. pp. 7-26.

Czabán, Cs., Alpek, A., Bártfai, A., Kertesy, A., Iványuk, Á., Benczúr, L., Takács, Sz., \& Kis, Gy. (2017a). A vallomások igazságtartamát meghamisítók típusai és vizsgálatuk kihallgatási helyzetben - 1 . rész, a meghamisító. Psychologia Hungarica Caroliensis, 4(2), 2016. pp. 27-35.

Czabán, Cs., Alpek, A., Bártfai, A., Kertesy, A., Iványuk, Á., Benczúr, L., Takács, Sz., \& Kis, Gy. (2017b). A vallomások igazságtartamát meghamisítók típusai és vizsgálatuk kihallgatási helyzetben - 2 . rész, az elhallgató. Psychologia Hungarica Caroliensis, 4(2), 2016. pp. 36-43.

Madzin, A., Alpek, A., Bártfai, A., Kertesy, A., Iványuk, Á., Benczúr, L., Takács, Sz., \& Kis, Gy. (2017a). A vallomások igazságtartamát meghamisítók típusai és vizsgálatuk kihallgatási helyzetben - 3 . rész, az eltitkoló. Psychologia Hungarica Caroliensis, 4(2), 2016. pp. 44-51.

Madzin, A., Alpek, A., Bártfai, A., Kertesy, A., Iványuk, Á., Benczúr, L., Takács, Sz., \& Kis, Gy. (2017d). A vallomások igazságtartamát meghamisítók típusai és vizsgálatuk kihallgatási helyzetben -4 . rész, a patetikus. Psychologia Hungarica Caroliensis, 4(2), 2016. pp. 52-59. 